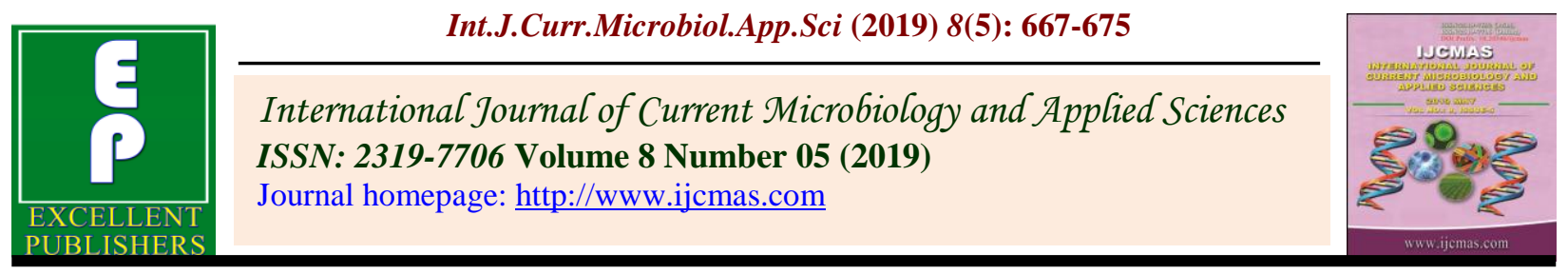

Original Research Article https://doi.org/10.20546/ijcmas.2019.805.078

\title{
Epidemiological study of Sheep and Goat pox Disease in Palestine during 2005-2017
}

\author{
Hatem Atalla* and Ibrahim Alzuheir \\ Department of Veterinary Medicine, An Najah National University, Nablus- Palestine \\ *Corresponding author
}

\section{Keywords \\ Epidemiology, \\ Sheep \\ Goat pox \\ disease, \\ Palestine \\ Article Info \\ Accepted: \\ 10 April 2019 \\ Available Online: \\ 10 May 2019}

\section{A B S T R A C T}

Palestine has a dense sheep and goat population. The number of small ruminants holdings farmed in the state over the years 2005-2017 decreased due to several constraints. The political situation in Palestine as well as the animal's diseases is among the important constraints that have hindered the development of the sector by decreasing production and hampering trade in animal and animal products. Analysis of quantitative retrospective sheep and goat pox (SGP) epidemiological data in Palestine based on reports of 'World Organization for Animal Health covering 13 years revealed significant information on the disease. Data revealed the endemic disease: there were a considerable number of outbreaks, high mortality and case fatality rates. SGP was reported in all of studied years. Temporally, the disease was most prevalent between January and February, reaching a peak in the lambing season. Vaccine coverage met only one-tenth of the requirement.

\section{Introduction}

Sheep and goat pox (SGP) disease is a major challenge of small ruminant industry in Palestine. The disease is a highly overwhelming systemic viral disease of sheep and goat. SGP disease is characterized by fever, skin and internal organs lesions, conjunctivitis, with oculonasal discharge and excess salivation (Maclachlan and Dubovi, 2010).
The economically important due to production losses because of decreased weight gain, milk yield, damage to wool and hides, cause abortion, and increased susceptibility to other diseases, while also being a direct cause of death (Bhanuprakash et al., 2006). The disease is more severe in young animal then adults. Infected animals can act as the main cause of spreading SGP viruses (Zangana and Abdullah, 2013). The causative agent of the disease is sheep and 
goat pox virus of family Poxoviaride, genus capripoxvirus. SGP virus can survive in the environment for a prolonged time and the virus is transmitted by the aerosol route, close contact and mechanically biting flies (Babiuk et al., 2008). The poxviruses of sheep and goat are distinct but hard to differentiate as recombination can occur (Hosamani et al., 2004). Today, SGP is found in most parts of the Middle East, North Africa, a portion of India, and central Asia (including south Russia and western China) (Babiuk et al., 2008). There is no effective drug for the treatment of the SGP disease. The control of the disease is limited by using antibacterial drugs to prevent secondary bacterial infection. It is also of importance that the animal should be vaccinated with the commercially available attenuated vaccine as the main control measure in endemic regions.

SGP is endemic in Palestine, and several outbreaks have been reported regularly in both West Bank and Gaza. Information on epidemiology is meager in Palestine. Hence, a study of the different aspects of SGP infection was necessary to understand the disease dynamics, mortality, incidence, and temporal distribution and other factors responsible for the persistence of infection in Palestine. Understanding of where, when and how the disease has occurred helps assess the risks, and to formulate appropriate preventative and reactive measures to decrease the infection or to eradicate the disease.

\section{Materials and Methods}

\section{Sheep and goat livestock in palestine 2005- 2017}

Information on the denominator sheep and goat populations in Palestine between 2005 and 2017 was collected. The primary source of these data was the Annual Agricultural Census released by the Palestinian Central
Bureau of Statistics conducted in Palestine (http://www.pcbs.gov.ps).

\section{SGP vaccination, annual and temporal trends}

The quantitative data on SGP pox outbreaks, cases, deaths and vaccinations were collected for the period 2005 to 2017. Data were based on reports of World Organization for Animal Health (http://www.oie.int/) submitted by Palestinian governmental veterinary services between 2005 and 2017.

\section{Analysis}

The present study consider the frequency of the outbreaks, incidence rate, incidence rate upon exposed, mortality rate, case fatality and vaccination rate of SGP diseases in each month of the year according to standard methods (Thrusfield, 2018). These epidemiological parameters were calculated according to the following formulae:

Incidence rate per 10,000 animals $=$ number of cases per year/ Total population of sheep and goat during that year $\times 10^{4}$

Incidence rate upon the exposed $=$ number of cases per year/ number of susceptible animals during that outbreak in the same year X 100

Infectious Mortality rate $=$ number of deaths /Number of susceptible animals during the outbreak at the same year X100

Mortality rate per 10,000 animals = number of deaths /Total population of sheep and goat during the same year $\mathrm{X} 10^{4}$

Case fatality rate $=$ number of deaths /number of cases

Vaccination rate $=$ total number of vaccinated animals / average population of sheep during that year X100 
The numbers of denominator populations of sheep and goat for the year 2017 has not published yet. No data for the SGP was published in 2007 from OIE and this year was excluded from the study. Data analyses were performed using GraphPad Prism 5 software (GraphPad Software Inc., San Diego, USA).

\section{Results and Discussion}

\section{Sheep and goat livestock in palestine 2005-} 2017

There is a subsequent trend of decreasing in the number of sheep and goat holding in Palestine during the study period. The total number of sheep and goats farmed in Palestine was decreased from 1.7 million in 2005 to 0.95 million in 2015, raised again in 2016 to 1.1 million (Figure 1). The sheep and goat population numbers for the year 2017 has not published yet.

\section{Cumulative profiles}

The retrospective quantitative data of SGP disease for the past 13 years in Palestine are shown in table 1 included the following information:

- An average annual sheep population of 1.18 million.

- An average immunization coverage rate of $12.0 \%$

- A total of 913 outbreaks, 7103 cases, and 465 deaths.

- The average incidence rate was $6.14 \%$ per annum per 10,000 animals.

- The average incidence rate upon exposed animals of $8.86 \%$.

- The average case fatality rate of $10.0 \%$.

\section{SGP Annual trends}

The present study finding showed that outbreaks occurred in all years (Figure 2), with the highest number occurring in 2005 $(n=312)$, followed by $2008 \quad(n=170)$. The lowest number reported in $2014(\mathrm{n}=3)$ and $2015(n=7)$ (Figure 2). The highest incidence rate per 10,000 animals was observed in 2005 $(34.23 \%)$, followed by $2008(9.51 \%)$ and $2006(6.66 \%)$; the lowest incidence rate occurred in $2014(0.08 \%)$. The highest mortality rate per 10,000 animals occurred in 2008 (1.75\%), followed by $2005(1.04 \%)$. Upon 26 outbreaks reported in 2015; there is no death. The lowest mortality rate was observed in 2015 (Table 1). The highest case fatality occurred in 2014 followed by 2008, and the lowest occurred in 2015. With regards to vaccination rate; the highest vaccination percentage was achieved in 2011 (21.54\%), followed by 2005, 2010 and 2006. The lowest vaccination percentage was in 2013 (4.08\%) (Table 1). The vaccination rate is not available for the years 2007, 2014, 2015 and 2017.

\section{Temporal distribution}

Data for various parameters were collated by month for the period January 2005 to December 2017. During this period, the disease occurred in all months of the year, but the highest number of outbreaks occurred in January (Table 2), (Figure 3). Most or reported outbreaks were occurred in winter season between January and February (Figure 3). The fewest outbreaks and the lowest incidence, mortality and coverage occurred in August, September and October (Table 2). The greatest mortality rate and case fatality rate were occurred in November. The disease trend tends to be more severe in December, April, May and June with the highest case fatality rate (Table 2).

\section{Trends in vaccine utilization}

The total utilization of the SGP vaccine was compared across different years. There is 
some limitation about the numbers of vaccinated animals from the years 2007 and 2015. The vaccine used is a live attenuated vaccine. The total of immunization coverage was 1.38 million animals with an average vaccination rate of $10.0 \%$. The annual utilization data showed that the highest number of doses $(250,228$ doses $)$ utilized with a vaccination rate of $21.31 \%$ achieved in 2005, whereas in 2012 only 34,769 doses were utilized, and the vaccination rate was $4.08 \%$ (Figure 4).

Table.1 Annual statistics of SGP in Palestine (2005-2017)

\begin{tabular}{|l|c|c|c|c|c|c|c|c|c|c|}
\hline Year & $\begin{array}{c}\text { No. } \\
\text { Outbreak }\end{array}$ & $\begin{array}{c}\text { No. } \\
\text { Cases }\end{array}$ & $\begin{array}{c}\text { No. } \\
\text { Susceptible }\end{array}$ & $\begin{array}{c}\text { No. } \\
\text { Deaths }\end{array}$ & $\begin{array}{c}\text { Incidence } \\
\text { (exposure } \\
(\mathbf{\%})\end{array}$ & $\begin{array}{c}\text { Infectious } \\
\text { Mortality } \\
(\mathbf{\%})\end{array}$ & $\begin{array}{c}\text { Incidence } \\
\mathbf{I 1 0}^{\mathbf{4}}\end{array}$ & $\begin{array}{c}\text { Mortality } \\
\text { rate /10 }\end{array}$ & $\begin{array}{c}\text { Case } \\
\text { fatality } \\
\mathbf{( \% )}\end{array}$ & $\begin{array}{c}\text { Vaccination } \\
(\mathbf{\%})\end{array}$ \\
\hline $\mathbf{2 0 0 5}$ & 312 & 4020 & 38661 & 122 & 10.40 & 0.32 & 34.23 & 1.04 & 3.03 & 21.31 \\
\hline $\mathbf{2 0 0 6}$ & 133 & 786 & 18402 & 76 & 4.27 & 0.41 & 6.66 & 0.64 & 9.67 & 11.97 \\
\hline $\mathbf{2 0 0 7}$ & 123 & NA & NA & NA & NA & NA & NA & NA & NA & NA \\
\hline $\mathbf{2 0 0 8}$ & 170 & 902 & 17004 & 166 & 5.30 & 0.98 & 9.51 & 1.75 & 18.40 & 12.12 \\
\hline $\mathbf{2 0 0 9}$ & 43 & 194 & 4612 & 17 & 4.21 & 0.37 & 1.66 & 0.15 & 8.76 & 5.95 \\
\hline $\mathbf{2 0 1 0}$ & 26 & 95 & 2485 & 5 & 3.82 & 0.20 & 0.52 & 0.03 & 5.26 & 12.79 \\
\hline $\mathbf{2 0 1 1}$ & 24 & 489 & 3209 & 17 & 15.24 & 0.53 & 5.03 & 0.17 & 3.48 & 21.45 \\
\hline $\mathbf{2 0 1 2}$ & 24 & 141 & 1421 & 2 & 9.92 & 0.14 & 0.70 & 0.01 & 1.42 & 9.67 \\
\hline $\mathbf{2 0 1 3}$ & 17 & 236 & 1673 & 20 & 14.11 & 1.20 & 2.77 & 0.23 & 8.47 & 4.08 \\
\hline $\mathbf{2 0 1 4}$ & 3 & 8 & 140 & 2 & 5.71 & 1.43 & 0.08 & 0.02 & 25.00 & NA \\
\hline $\mathbf{2 0 1 5}$ & 7 & 26 & 371 & 0 & 7.01 & 0.00 & 0.28 & 0.00 & 0.00 & NA \\
\hline $\mathbf{2 0 1 6}$ & 17 & 153 & 875 & 29 & 17.49 & 3.31 & NA & NA & 18.95 & 12.3 \\
\hline $\mathbf{2 0 1 7}$ & 14 & 53 & 865 & 9 & 6.13 & 1.04 & NA & 6.13 & 16.98 & NA \\
\hline
\end{tabular}

Table.2 Seasonality of SGP in Palestine (January 2005 to December 2016)

\begin{tabular}{|l|c|c|c|c|c|c|c|}
\hline Month & $\begin{array}{c}\text { No. } \\
\text { Outbreak }\end{array}$ & $\begin{array}{c}\text { No. } \\
\text { Cases }\end{array}$ & $\begin{array}{c}\text { No. } \\
\text { Susceptible }\end{array}$ & $\begin{array}{c}\text { No. } \\
\text { Deaths }\end{array}$ & $\begin{array}{c}\text { Infectious } \\
\text { Morbidity } \mathbf{( \% )}\end{array}$ & $\begin{array}{c}\text { Mortality } \\
\text { rate /104 }\end{array}$ & $\begin{array}{c}\text { Case fatality } \\
\text { rate }\end{array}$ \\
\hline Jan & 109 & 1182 & 11105 & 76 & 10.64 & 0.68 & 6.43 \\
\hline Feb & 92 & 363 & 6171 & 11 & 5.88 & 0.18 & 3.03 \\
\hline Mar & 55 & 740 & 10349 & 66 & 7.15 & 0.64 & 8.92 \\
\hline Apr & 77 & 427 & 7402 & 42 & 5.77 & 0.57 & 9.84 \\
\hline May & 76 & 494 & 7159 & 47 & 6.90 & 0.66 & 9.51 \\
\hline Jun & 57 & 612 & 7175 & 54 & 8.53 & 0.75 & 8.82 \\
\hline Jul & 53 & 613 & 5955 & 39 & 10.29 & 0.65 & 6.36 \\
\hline Aug & 53 & 599 & 5439 & 7 & 11.01 & 0.13 & 1.17 \\
\hline Sep & 41 & 375 & 6691 & 16 & 5.60 & 0.24 & 4.27 \\
\hline Oct & 41 & 578 & 6942 & 23 & 8.33 & 0.33 & 3.98 \\
\hline Nov & 44 & 476 & 5285 & 48 & 9.01 & 0.91 & 10.08 \\
\hline Dec & 42 & 565 & 6659 & 24 & 8.48 & 0.36 & 4.25 \\
\hline
\end{tabular}


Figure.1 Sheep and goat numbers holdings each year 2005-2016 in Palestine.

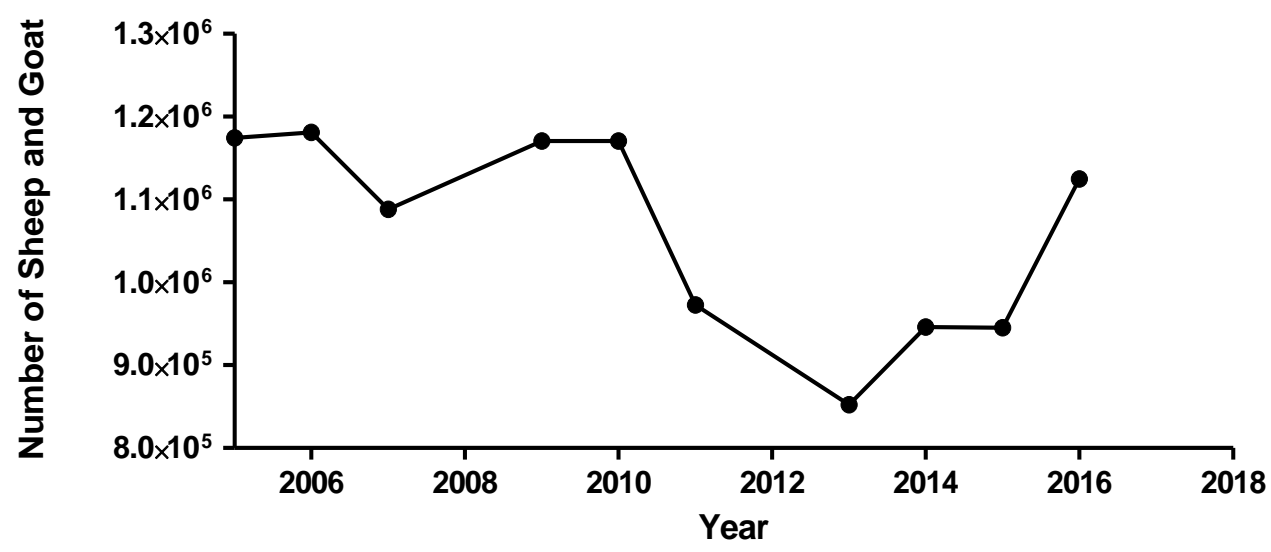

Figure.2 Numbers of sheep and goat pox outbreaks in Palestine each year 2005-2017

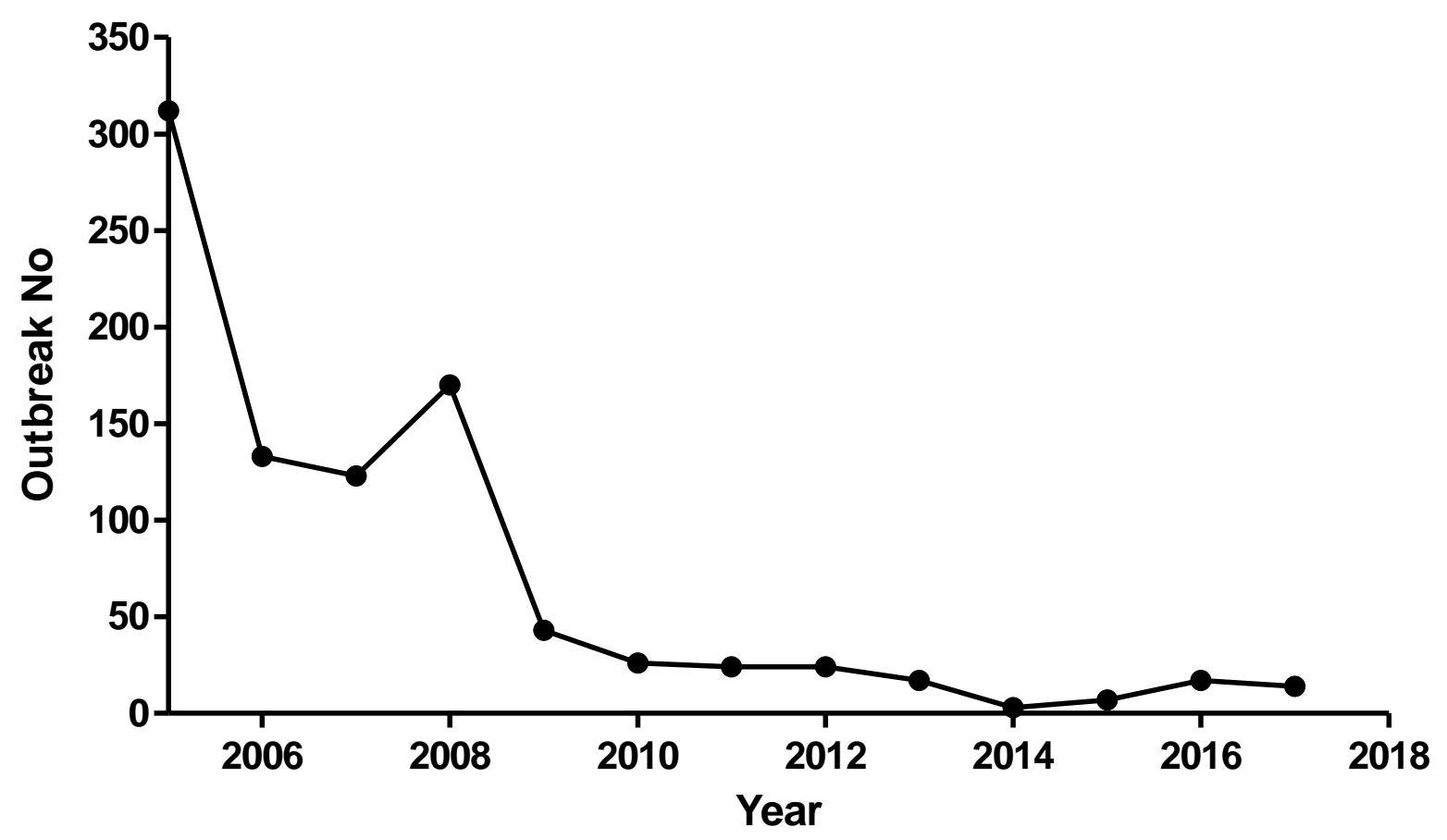


Figure.3 Seasonality of SGP in Palestine (January 2005 to December 2017)

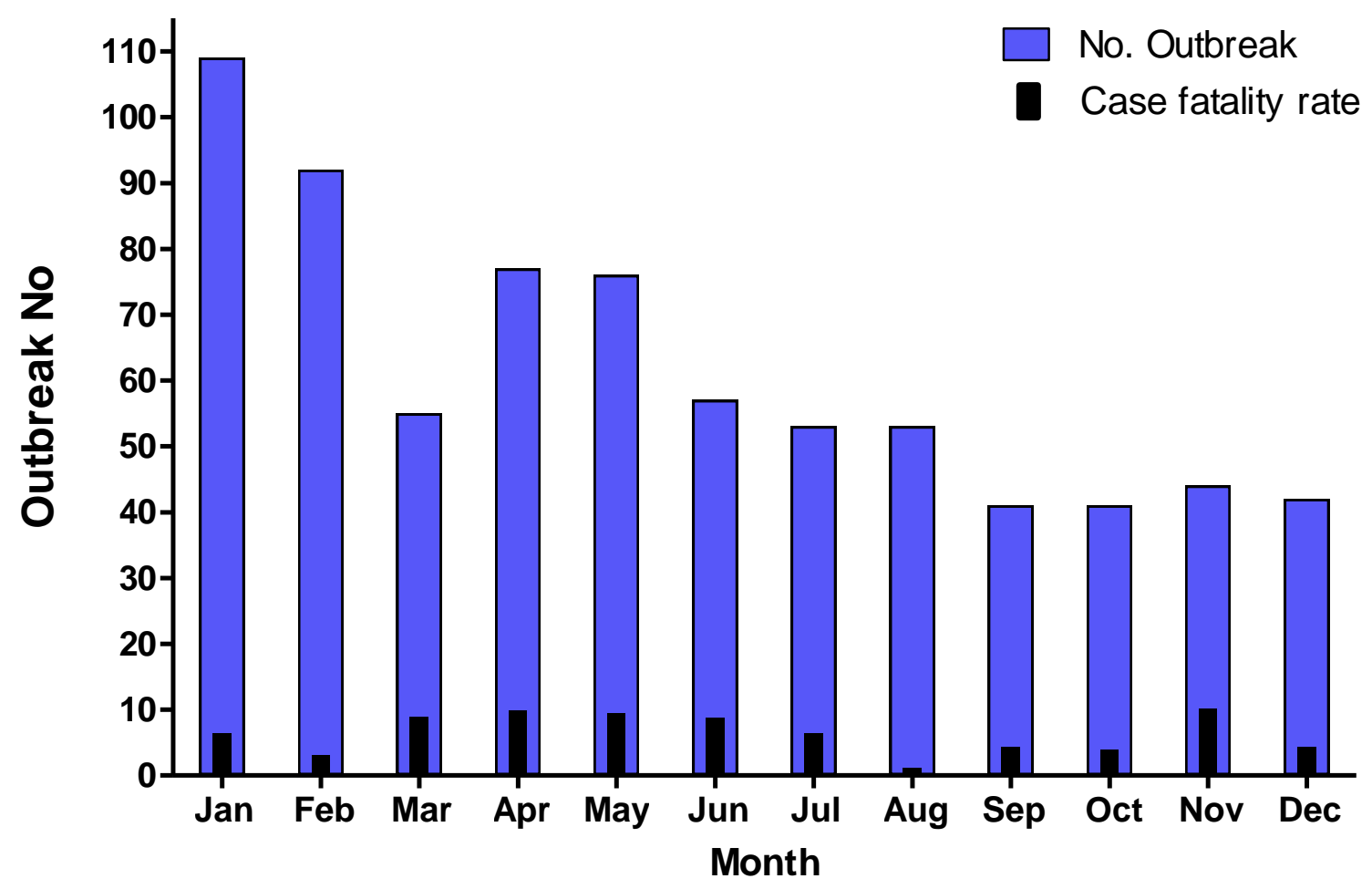

Figure.4 Vaccination rate of SGP in Palestine during 2005-2017.

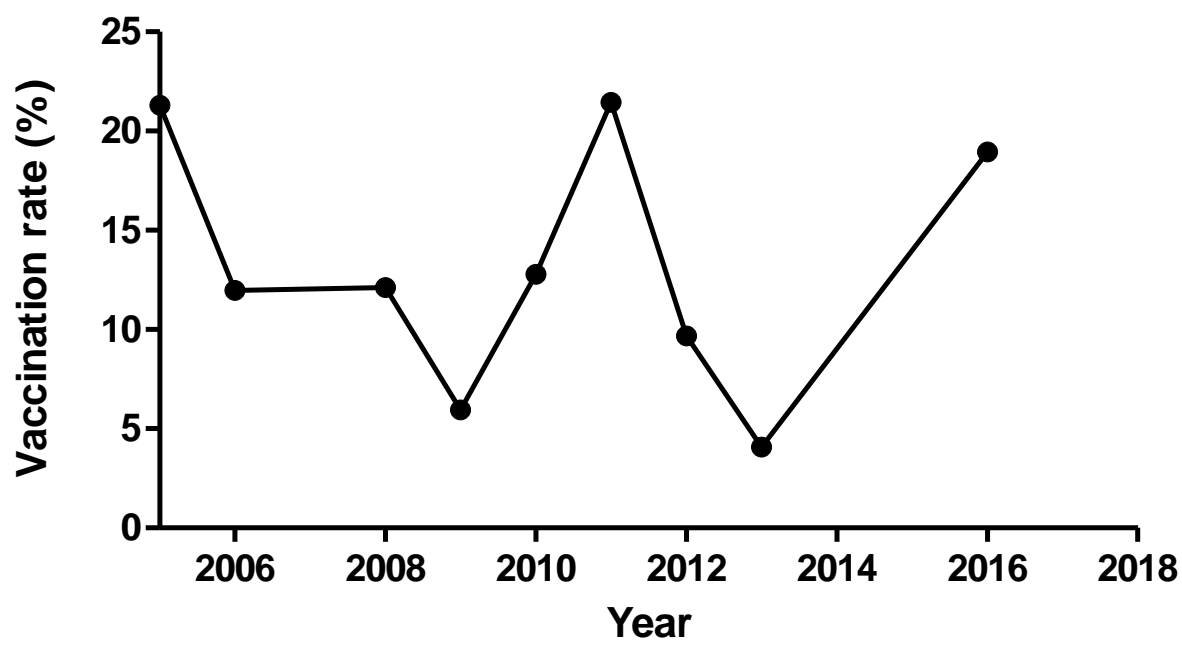

Small ruminants (sheep and goats) have an important value in the Palestinian tradition, as well as the economy (statistics, 2014). They have made a significant contribution to both domestic market through the provision of food (meat and milk) and non-food (manure, skin, and wool) products and support survival for Palestinian people. In addition, they help to provide extra income for many farmers in Palestine. The aim of this work was to 
systematically review the occurrence of sheep and goat pox disease (SGP) in sheep and goat in Palestine over the 13 years 2005-2017. Our findings represented in figures and tables to allow the reader to evaluate the trends and data for SGP. We discussed the trends observed in numbers of sheep and goat population in Palestine as well as the SGP disease occurrence. The results showed a decline in sheep and goat population holding in Palestine during the study period. This decline is mostly related to several limitations; some of them due to the Palestinian political situation. The continues evacuation of Palestinian villages led to this tremendous alteration in the animal population density and to losses of some local breeds (Falah, 1996). Furthermore, resources needed for raising farm animals are being diminished on an ongoing basis by Israeli measures (Al Baqain and Zárate, 2011). The global increase in the feed price with the ongoing confiscation of grazing land in the West Bank by illegal Israeli settlements limits Palestinians' ability to cultivate the land and use it for grazing. In addition, the decrease in the availability of water required to irrigate crops and water animals increase the cost of rearing (Abu Hammad and Tumeizi, 2012). The inequitable distribution of water between settlers and Palestinians has been widely documented (Falah, 1996). The sheep and goat farm in Palestine had remained relatively stable over the years 2014-2016 (Figure 1).

Besides the Palestinian political situation, analysis of retrospective quantitative data for sheep and goat pox (SGP) during the past 13 years revealed a considerable number of outbreaks in Palestine. These findings implying that SGP is highly endemic in Palestine, thus considered a serious problem. Apparent reasons for these outbreaks include low vaccination coverage compared to the sheep population, vaccination failure and environmental conditions (Babiuk et al., 2008). The host factors responsible could also include age, sex, breed and physiological, nutritional and immunological status, these factors have not been discussed here. With the available data, it was not possible to differentiate the impact of SGP on the various breeds of sheep and goat and to correlate the host risk factors as well as the environmental factors (Yune and Abdela, 2017). This discussion was focused on the general patterns of the frequency and incidence of SGP in Palestine and on the factors that affected disease occurrence. The limitations of the available data regarding these factors affect our results. The occurrence of the SGP diseases in Palestine from 2005 to 2017 was evaluated with several indexes. First, the annual incidence of the diseases on sheep and goat was estimated. The incidence range was 0.28 to 34.4 per 10,000 animals, our finding is similar to other studies of the epidemiology of the disease in Greece where the incidence rate was ranged from 4.21 per 100,000 to 59.87 per 100,000 (Mangana et al., 2008). A decline of SGP outbreaks was eventually achieved from 2005 to 2017. During 2005 we observed the highest frequency of SGP incidents in Palestine. This high incidence rate is attributed to various factors, such as efficient reporting of outbreaks at that time, a higher number of susceptible animals and host/agent factors. Figure 3 presents the number of seasonal peaks of SGP in Palestine showed activities peaked during the winter season (between January and February). Interestingly, low indices were reported during the summer periods. Fall peaks were also reported in Iraq (Zangana and Abdullah, 2013), Egypt (Bhanuprakash et al., 2006), Jordan (Hailat et al., 1994) India (Garner et al., 2000) and Algeria (Kardjadj, 2017). The high case fatality rate indicates the severity of the disease, the higher number of susceptible animals during the lambing season and the fact that attributed to the ability of the virus to persist for many months in wet and cold weather. It is very likely that the housing of 
the animals in crowded enclosures facilitated transmission of the virus (Yeruham et al., 2007). In addition, the poor physiological condition of flocks in the autumn increase the severity of the disease (Kardjadj, 2017).

Sheep and goat have many advantages as these domestic animals are that they require small investments; faster growth rates and has shorter production cycles. Unfortunately, the political instability in Palestine has a great impact on sheep and goat population. SGP disease is endemic in Palestine and contributed to economic loses. The insufficiency of data regarding sheep and goat population as well as the occurrence of the disease limits the systematic analysis during all the years. Consistent recording of such information would improve the analysis of disease outbreaks and control measures. With the available data, the disease occurs throughout the year but is most prevalent during the months of January to May, reaching a peak in the lambing season. Hence, the appropriate time to vaccinate flocks is at the beginning of December. Unfortunately, the nature of sheep and goat farming make vaccination campaigns problematic.

\section{References}

Abu Hammad, A., Tumeizi, A., 2012. Land degradation: socioeconomic and environmental causes and consequences in the eastern Mediterranean. Land Degradation \& Development 23, 216226.

Al Baqain, R., Zárate, A.V., 2011. Economic analysis of Bedouin sheep farming in Jordan and the Palestinian territories. Livestock Research for Rural Development. Volume 23, Article 249.

Babiuk, S., Bowden, T.R., Boyle, D.B., Wallace, D.B., Kitching, R.P., 2008. Capripoxviruses: an emerging worldwide threat to sheep, goats and cattle. Transbound Emerg Dis 55, 263272.

Bhanuprakash, V., Indrani, B., Hosamani, M., Singh, R., 2006. The current status of sheep pox disease. Comparative immunology, microbiology and infectious diseases 29, 27-60.

Falah, G., 1996. The 1948 Israeli-Palestinian War and its aftermath: The transformation and de-signification of Palestine's cultural landscape. Annals of the Association of American Geographers 86, 256-285.

Garner, M.G., Sawarkar, S.D., Brett, E.K., Edwards, J.R., Kulkarni, V.B., Boyle, D.B., Singh, S.N., 2000. The extent and impact of sheep pox and goat pox in the state of Maharashtra, India. Trop Anim Health Prod 32, 205-223.

Hailat, N., al-Rawashdeh, O., Lafi, S., alBateineh, Z., 1994. An outbreak of sheep pox associated with unusual winter conditions in Jordan. Trop Anim Health Prod 26, 79-80.

Hosamani, M., Mondal, B., Tembhurne, P.A., Bandyopadhyay, S.K., Singh, R.K., Rasool, T.J., 2004. Differentiation of sheep pox and goat poxviruses by sequence analysis and PCR-RFLP of P32 gene. Virus genes 29, 73-80.

Kardjadj, M., 2017. Prevalence, distribution, and risk factor for sheep pox and goat pox (SPGP) in Algeria. Trop Anim Health Prod 49, 649-652.

Maclachlan, N.J., Dubovi, E.J., 2010. Fenner's veterinary virology. Academic press.

Mangana, O., Kottaridi, C., Nomikou, K., 2008. The epidemiology of sheep pox in Greece from 1987 to 2007. Rev Sci Tech 27, 899-905.

statistics, P.c.b.o., 2014. Livestock Survey, 2013 - Main Results. In. Palestinian central bureau of statistics, City, p. 63.

Thrusfield, M., 2018. Veterinary epidemiology. John Wiley \& Sons. 
Yeruham, I., Yadin, H., Ham, M.v., Bumbarov, V., Soham, A., Perl, S., Tzivara, A., Kritas, S., Bourriel, A., Alexopoulos, C., 2007. 1135701. Economic and epidemiological aspects of an outbreak of sheeppox in a dairy sheep flock. The Veterinary Record 160, 236-237.

Yune, N., Abdela, N., 2017. Epidemiology and economic importance of sheep and goat pox: a review on past and current aspects. J Vet Sci Technol 8, 1-5.

Zangana, I., Abdullah, M., 2013. Epidemiological, clinical and histopathological studies of lamb and kid pox in Duhok, Iraq. Bulgarian Journal of Veterinary Medicine 16, 133138.

\section{How to cite this article:}

Hatem Atalla and Ibrahim Alzuheir. 2019. Epidemiological study of Sheep and Goat pox Disease in Palestine during 2005-2017. Int.J.Curr.Microbiol.App.Sci. 8(05): 667-675. doi: https://doi.org/10.20546/ijcmas.2019.805.078 